\title{
Hyponatremia - unfavourable prognostic factor in hepatic cirrhosis
}

\author{
AURELIA ENESCU, F. PETRESCU, P. MITRUȚ, V. PĂDUREANU, OCTAVIA ILEANA PETRESCU, \\ VALERIA CARMEN ALBU, ANDREEA LARISA MORARU, ANCA ŞTEFANIA ENESCU
}

University of Medicine and Pharmacy, Craiova, Romania

\begin{abstract}
Hyponatremia is defined by a level of $\mathrm{Na}$ in serum below or equal to $136 \mathrm{mEq} / \mathrm{L}$ while in hepatic cirrhosis it is classically considered as relevant only at a level of Na below $130 \mathrm{mEq} / \mathrm{L}$.

Hyponatremia frequently occurs in patients with end-stage hepatic disease. The frequency and severity are variable but it has been estimated that it occurs with a frequency of $57 \%$ in hospitalized patients with cirrhosis and in those on waiting lists for hepatic transplants. Signs and symptoms of hyponatremia are related to dysfunctions of the central nervous system, due to migration of the water from intravascular space to the brain cells, resulting in the occurrence of cerebral edema. Therapeutic options in hyponatremia are limited and are based on restriction of water consumption, exclusion of diuretics and vaptans. Hepatic transplant remains the only definitive treatment for end-stage hepatic diseases in which hyponatremia has occurred.
\end{abstract}

Key words: hyponatremia, liver cirrhosis, hepatic transplant, portal hypertension, antidiuretic hormone.

\section{INTRODUCTION}

Hyponatremia frequently occurs in patients with end-stage hepatic diseases. Incidence and severity are variable, but it has been estimated that it occurs with a frequency of $57 \%$ in hospitalized patients with cirrhosis. Hyponatremia represents an imbalance of electrolytes in patients with advanced hepatic disease. In cirrhosis, hyponatremia can be classified either as hypovolemic hyponatremia, which can occur after diuretic treatment or excessive fluid loss from the gastrointestinal tract, or as hypervolemic hyponatremia which results from increased arterial splanchnic dilatation that leads to excessive secretion of arginine-vasopressin [1,2]. Hyponatremia is associated with a high mortality rate in patients with cirrhosis and in those on waiting lists for hepatic transplants [3]. It has not been proven that the treatment for hyponatremia improves the survival rate of patients with advanced-stage hepatic disease and rapid correction can lead to life-threatening neurological complications.

\section{PREVALENCE}

Recent data indicate the fact that hyponatremia is present in patients with cirrhosis and portal hypertension. Approximately half of the patients with cirrhosis have a serum $\mathrm{Na}$ level below $130 \mathrm{mEq} / \mathrm{L}$ $[1,4]$. Angelli et al. describe a prevalence as high as $57 \%$. Prevalence of hyponatremia in patients with end-stage hepatic disease that are on waiting lists for hepatic transplant is variable. Ginès and Cárdenas [5] have shown that hyponatremia occurs before transplant in $42 \%$ of these patients $(\mathrm{Na}<130$ $\mathrm{mEq} / \mathrm{L}$ ) and hyponatremia persists only in $16 \%$ of the patients after hepatic transplant.

\section{PATHOPHYSIOLOGY}

Hyponatremia is defined by the sodium level in the serum below or equal to $136 \mathrm{mEq} / \mathrm{L}$, while in cirrhosis it is considered relevant only at levels of sodium below $130 \mathrm{mEq} / \mathrm{L}$.

As a rule, hyponatremia can be classified in 3 clinical types:

- hypovolemic;

- euvolemic;

- hypervolemic.

There are cases of hyponatremia, called dilution hyponatremia, which occurs when serum is hypotonic and extracellular fluid volume elevated. In this case, there is an abnormality in the excretion of free water in the presence of ADH excess. Diseases that are associated with this type of hyponatremia include but are not limited to cirrhosis, myocardial infarction, certain types of renal failure and nephritic syndrome [4]. In cirrhosis, hyponatremia occurs in conditions of expanded extracellular fluid. Total water deposits in the body are increased at high level; despite this fact, effective arterial volume is low [2]. The decrease of effective arterial volume is 
a consequence of arterial splanchnic vasodilatation, which is mediated by the excessive production of nitric oxide and other components that exert a vasodilatatory effect, such as endotoxin, substance P, endogen cannabinoids that regulate the elevated intrahepatic resistance $[5,6]$. This process leads to the necessity of sodium in the proximal segment of the nephron by the activation of the renin-angiotensin-aldosterone axis and excess of ADH reabsorption of free water in the collector tubes. It has been shown that arterial baroreceptors found in specific areas, for example the left ventricle and carotid sinuses, are regulators of $\mathrm{ADH}$ secretion that can counterbalance the suppressive effects of hypoosmolarity. In patients with cirrhosis and ascites, non-osmotic release of $\mathrm{ADH}$ from the posterior pituitary gland becomes the dominant element, resulting in an impairment in the free water excretion and consequently, dilution hyponatremia.

\section{CLINICAL MANIFESTATIONS}

Signs and symptoms of hyponatremia are related to the central nervous system dysfunctions, due to migration of water from intravascular space towards the brain cells, resulting in cerebral edema. Hyponatremia that occurs in hepatic cirrhosis has been described as an independent mortality risk factor and is a common finding in patients with end-stage hepatic disease $[4,7]$. A study conducted in 2006 on 997 patients suffering from cirrhosis showed a prevalence of $21.6 \%$ of sodium levels in serum below $130 \mathrm{mEq} / \mathrm{L}$ [3]. In this subgroup of patients, the incidence of hepatorenal syndrome and spontaneous bacterial peritonitis was significantly increased. In patients with sodium levels below $135 \mathrm{mEq} / \mathrm{L}$, refractory ascites and the need for paracentesis were also higher.

A number of factors, including the rate, extension and time of serum sodium decrease, determine the presence of clinical symptoms of hyponatremia.

Most of the patients with sodium in the serum below $135 \mathrm{mEq} / \mathrm{L}$ are asymptomatic; this is due to the activation of cerebral adaptive mechanisms. Neurological symptoms are common when sodium drops below these levels [8]. A recent study on 525 patients suffering from cirrhosis complicated with ascites demonstrated that life quality was significantly lower in patients with hyponatremia and levels of sodium in serum below $130 \mathrm{mEq} / \mathrm{L}$ [9]. This effect was independent of the severity of the disease and was represented by hepatic insufficiency or by a high score of end-stage hepatic disease. It is important to take note of the fact that the quality of life in these patients was also negatively influenced in those presenting mild hyponatremia, with sodium levels of $130-135 \mathrm{mEq} / \mathrm{L}$.

Recent data indicate the fact that hyponatremia is an important predictive factor of the quality of life of these patients in a negative way, independent of cognitive dysfunction. This situation can be improved through diuretic therapy in patients in which sodium reaches high levels [1].

Patients with acute hyponatremia (hyponatremia occurring in 48 hours) are at risk for developing neurological dysfunctions and, in consequence, need a rapid correction of sodium levels in the serum; this can be achieved by administering hypertonic saline solution. In patients with chronic hyponatremia, benefits of electrolytic correction should be assessed thoroughly because of the risk of developing an osmotic process that is associated with a too rapid correction of sodium in the serum.

In some studies, hepatic encephalopathy was demonstrated to be aggravated by the presence of hyponatremia. Hyponatremia with sodium below $130 \mathrm{mEq} / \mathrm{L}$ is one of the predictive factors for the occurrence of hepatic encephalopathy at one year, along with high levels of serum creatinine and bilirubin.

Spontaneous bacterial peritonitis is often associated with significant morbidity, including renal failure. Patients with hyponatremia at the time of the diagnosis of spontaneous bacterial peritonitis present a high risk for developing hepato-renal syndrome and death [6]. Cirrhotic patients with hyponatremia and renal failure hospitalized for infections also present a higher risk than patients without infections. This has been associated with a higher 3-months mortality rate compared with patients without hyponatremia and renal failure [10].

\section{TREATMENT}

Therapeutic options for patients with cirrhosis and hyponatremia are limited. The first step should consist in identifying and correcting the causes of hyponatremia, which include taking the patients off diuretic treatment and eliminating other causes of gastrointestinal loss. Patients with hypovolemia and prerenal azotemia should be administered intravenous crystalloids or albumin. It is important to recognize patients with hepatic cirrhosis that develop real hypovolemic hyponatremia. The benefits of the treatment should be considered more important that potential risks. Severe hyponatremia with sodium $<120 \mathrm{mEq} / \mathrm{L}$ is not specific for 
cirrhosis, occurring in $1.2 \%$ of the patients. The use of hypertonic saline solutions can lead to the aggravation of ascites or the secondary edema due to the deficit at the nephron level and should be reserved only to acute situations. In order to avoid neurological complications, in patients with chronic hyponatremia this should not be corrected with more than $12 \mathrm{mmol}$ in 24 hours and $18 \mathrm{mmol}$ in 48 hours.

Since AVP release is a primary cause of hyponatremia in cirrhosis, several antagonists of vasopressin receptors have been assessed in the treatment of hyponatremia in patients with cirrhosis and other conditions characterized by hypovolemic hyponatremia. Only Conivaptan and Talvaptan are approved for raising the levels of serum sodium in patients with hypervolemia and hyponatremia.

Conivaptan is administered intravenous in doses of $20 \mathrm{mg}$, followed by continuous perfusion with $20 \mathrm{mg}$ for two to four days.

Talvaptan is indicated in the treatment of hypervolemic or euvolemic hyponatremia that is clinically significant, characterized by sodium levels equal to or below $125 \mathrm{mEq} / \mathrm{L}$ - hyponatremia that is resistant to correction by fluid restriction.

Talvaptan is contraindicated in patients with hypovolemic hyponatremia, in those patients who need an urgent elevation of serum sodium, in patients that need prevention or treatment of neurological symptoms and in anuric patients.

The most frequent adverse effects of vaptans include thirst and dry mouth, which occur in $29 \%$ of the patients tested in clinical trials [11]. Other adverse effects are represented by dehydration, renal insufficiency, orthostatic hypotension, encephalopathy and hypercalcemia [12].

It seems that hyponatremia has an important clinical impact after hepatic transplant. Pacients with hyponatremia before transplant can develop delirium, renal insuficiency and infections in the first month after transplant [9].

Londoño et al. have described a 3-months survival rate of $84 \%$ in patients with hyponatremia compared to a $94 \%$ survival rate in those without hyponatremia.

\section{CONCLUSIONS}

Hyponatremia is common in patients with end-stage hepatic disease. A low level of sodium in serum is a negative prognostic marker before and after liver transplant and an increase in mortality risk and complications such as infections, acute renal insufficiency and encephalopathy has been proven. Treatment options are limited and, at this time, are limited to the restriction of water intake, exclusion of diuretics and vaptans. Hepatic transplant remains the only definitive treatment for end-stage hepatic disease complicated with hyponatremia. Vaptans can be useful if administered in the peritransplant period.

Conflicts of interest. There are no conflicts of interest.

All authors have equal contributions.

Hiponatremia este definită printr-un nivel al Na seric mai mic sau egal cu $136 \mathrm{mEq} / \mathrm{L}$, în timp ce în ciroza hepatică este considerat relevant doar la nivelul de Na sub $130 \mathrm{mEq} / \mathrm{L}$.

Hiponatremia apare frecvent la pacienții cu boală hepatică în stadiu terminal. Frecvența şi severitatea sunt variabile, dar s-a dovedit că au o frecvență de $57 \%$ la pacienții spitalizați cu ciroză hepatică şi la cei de pe listele de aşteptare pentru transplantul hepatic. Semnele şi simptomele hiponatremiei sunt legate de disfuncții ale sistemului nervos central, ca urmare a migrării apei din spațiul intravascular la celulele cerebrale, ducând la apariția edemului cerebral. Opțiunile terapeutice pentru hiponatremie sunt limitate şi se bazează pe restricționarea consumului de apă, excluderea diureticelor şi vaptanilor. Transplantul hepatic rămâne singurul tratament definitiv pentru bolile hepatice în stadiu terminal, în care este prezentă hiponatremia.

Correspondence to: Vlad Pădureanu, MD, PhD, University of Medicine and Pharmacy Craiova, Romania

2 Petru Rares street, Craiova, Dolj, 200349, Romania

Mobile: + 40722567874

E-mail: vldpadureanu@gmail.com or vldpadureanu@yahoo.com 


\section{REFERENCES}

1. EUROPEAN ASSOCIATION FOR THE STUDY OF THE LIVER. EASL clinical practice guidelines on the management of ascites, spontaneous bacterial peritonitis and hepatorenal syndrome in cirrhosis. J Hepatol. 2010; 53(3):397-417.

2. SCHRIER RW. Water and sodium retention in edematous disorders: Role of vasopressin and aldosterone. Am J Med. 2006; 119(7 Suppl 1):S47-53.

3. ADROGUÉ HJ, MADIAS NE. Hyponatremia. N Engl J Med. 2000; 342(21):1581-9.

4. BIGGINS SW, RODRIGUEZ HJ, BACCHETTI P, BASS NM, ROBERTS JP, TERRAULT NA. Serum sodium predicts mortality in patients listed for liver transplantation. Hepatology. 2005; 41(1):32-39.

5. GINÈS P, CÁRDENAS A. The management of ascites and hyponatremia in cirrhosis. Semin Liver Dis. 2008; 28(1):43-58.

6. FOLLO A, LLOVET JM, NAVASA M, PLANAS R, FORNS X, FRANCITORRA A, et al. Renal impairment after spontaneous bacterial peritonitis in cirrhosis: incidence, clinical course, predictive factors and prognosis. Hepatology. 1994; 20(6): $1495-1501$.

7. ARROYO V, RODÉS J, GUTIÉRREZ-LIZÁRRAGA MA, REVERT L. Prognostic value of spontaneous hyponatremia in cirrhosis with ascites. Am J Dig Dis. 1976; 21(3):249-56.

8. LONDOÑO MC, GUEVARA M, RIMOLA A, NAVASA M, TAURÀ P, MAS A, et al. Hyponatremia impairs early posttransplantation outcome in patients with cirrhosis undergoing liver transplantation. Gastroenterology. 2006; 130(4):1135-43.

9. SOLÀ E, WATSON H, GRAUPERA I, TURÓN F, BARRETO R, RODRÍGUEZ E, et al. Factors related to quality of life in patients with cirrhosis and ascites: relevance of serum sodium concentration and leg edema. J Hepatol. 2012; 57(6):1199-206.

10. PEREIRA G, GUEVARA M, FAGUNDES C, SOLÁ E, RODRÍGUEZ E, FERNÁNDEZ J, et al. Renal failure and hyponatremia in patients with cirrhosis and skin and soft tissue infection. A retrospective study. J Hepatol. 2012; 56(5):1040-46.

11. CÁRDENAS A, GINÈS P, MAROTTA P, CZERWIEC F, OYUANG J, GUEVARA M, et al. Tolvaptan, an oral vasopressin antagonist, in the treatment of hyponatremia in cirrhosis. J Hepatol. 2012; 56(3):571-8.

12. BERL T, QUITTNAT-PELLETIER F, VERBALIS JG, SCHRIER RW, BICHET DG, OUYANG J, et al. Oral tolvaptan is safe and effective in chronic hyponatremia. J Am Soc Nephrol. 2010; 21(4):705-12.

Received April 15, 2016 